
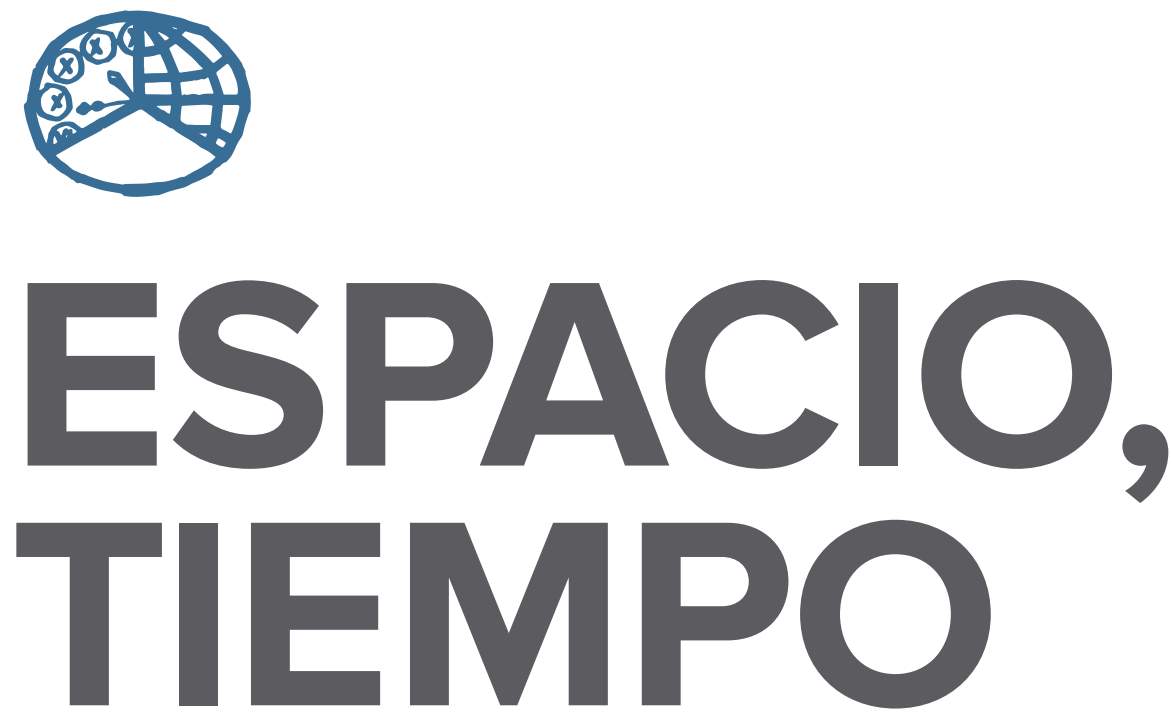

AÑO 2015 NUEVA ÉPOCA ISSN $1130-4715$

E-ISSN 2340-1478
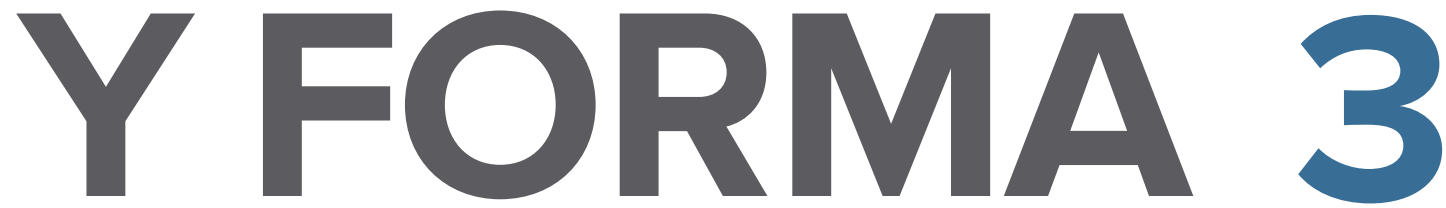

SERIE VII HISTORIA DEL ARTE

REVISTA DE LA FACULTAD DE GEOGRAFÍA E HISTORIA 

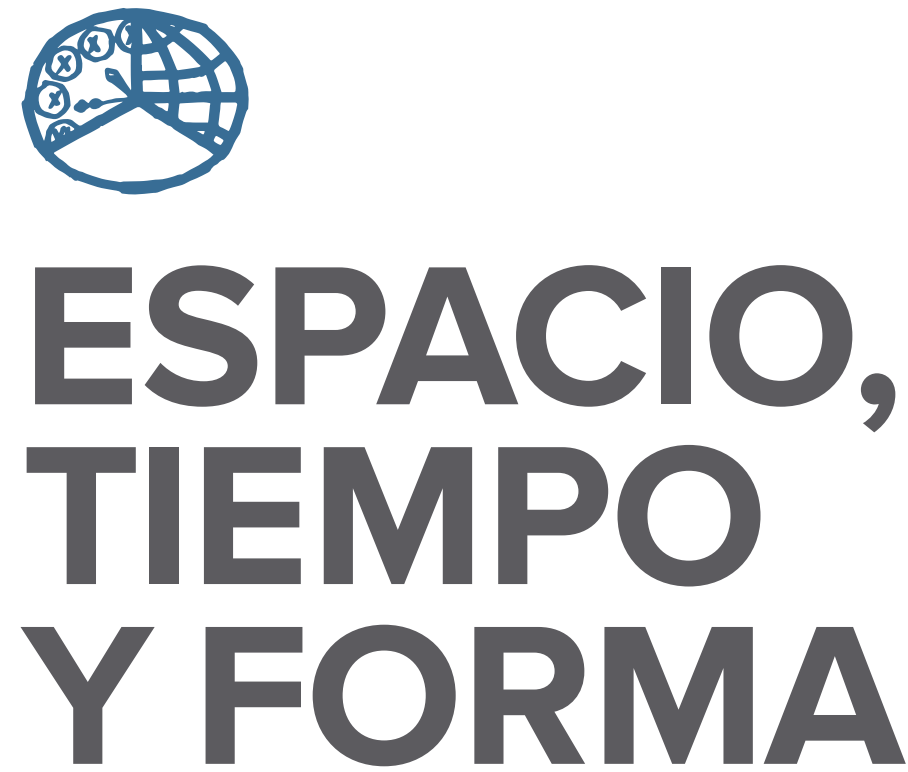

AÑO 2015

NUEVA ÉPOCA

ISSN 1130-4715

E-ISSN 2340-1478

SERIE VII HISTORIA DEL ARTE

REVISTA DE LA FACULTAD DE GEOGRAFÍA E HISTORIA

DOI: http://dx.doi.org/10.5944/etfvii.3.2015

\section{UกED}

UNIVERSIDAD NACIONAL DE EDUCACIÓN A DISTANCIA 
La revista Espacio, Tiempo y Forma (siglas recomendadas: ETF), de la Facultad de Geografía e Historia de la UNED, que inició su publicación el año 1988, está organizada de la siguiente forma:

$$
\begin{aligned}
& \text { SERIE I - Prehistoria y Arqueología } \\
& \text { SERIE II - Historia Antigua } \\
& \text { SERIE III - Historia Medieval } \\
& \text { SERIE IV - Historia Moderna } \\
& \text { SERIE V - Historia Contemporánea } \\
& \text { SERIE VI - Geografía } \\
& \text { SERIE VII - Historia del Arte }
\end{aligned}
$$

Excepcionalmente, algunos volúmenes del año 1988 atienden a la siguiente numeración:

$$
\begin{aligned}
& \mathrm{N} .^{\circ} 1 \text { - Historia Contemporánea } \\
& \mathrm{N}^{\circ} 2 \text { - Historia del Arte } \\
& \text { N. }{ }^{\circ} 3 \text { - Geografía } \\
& \mathrm{N} .^{\circ} 4 \text { - Historia Moderna }
\end{aligned}
$$

ETF no se solidariza necesariamente con las opiniones expresadas por los autores.

Espacio, Tiempo y Forma, Serie vII está registrada e indexada, entre otros, por los siguientes Repertorios Bibliográficos y Bases de Datos: DICE, ISOC (CINDOC), RESH, IN-RECH, Dialnet, e-sPacio, UNED, CIRC, MIAR, FRANCIS, PIO, ULRICH'S, SUDOC, 2DB, ERIH (ESF).

\author{
UNIVERSIDAD NACIONAL DE EDUCACIÓN A DISTANCIA \\ Madrid, 2015 \\ SERIE VII · HISTORIA DEL ARTE (NUEVA ÉPOCA) N. ${ }^{\circ} 3,2015$ \\ ISSN $1130-4715 \cdot$ E-ISSN 2340-1478 \\ DEPÓSITO LEGAL \\ M-21.037-1988 \\ URL \\ ETF VII · HISTORIA DEL ARTE · http://revistas.uned.es/index.php/ETFVII \\ DISEÑO Y COMPOSICIÓN \\ Ángela Gómez Perea · http://angelagomezperea.com \\ Sandra Romano Martín · http://sandraromano.es \\ Impreso en España · Printed in Spain
}

(c) (i) (8) Esta obra está bajo una licencia Creative Commons

Reconocimiento-NoComercial 4.0 Internacional. 


\section{DOSSIER}

ART IN THE FRANCO ERA:

TENDENCIES ON THE FRINGE OF A STATE IDEOLOGY

Coordinated by Victor Nieto Alcaide,

with the collaboration of Genoveva Tusell García

ARTE EN EL FRANQUISMO:

TENDENCIAS AL MARGEN DE UNA IDEOLOGÍA DE ESTADO

Coordinado por Víctor Nieto Alcaide,

con la colaboración de Genoveva Tusell García 


\title{
THE EXHIBITION
}

\section{ARTE DE AMÉRICA Y ESPAÑA (1963): THE CONTINUATION OF THE SPIRIT OF THE HISPANOAMERICAN BIENNIALS}

\section{LA EXPOSICIÓN ARTE DE AMÉRICA Y ESPAÑA (1963), CONTINUADORA DEL ESPÍRITU DE LAS BIENALES HISPANOAMERICANAS}

\author{
Genoveva Tusell García (guest editor) \\ DOI: http://dx.doi.org/10.5944/etfvii.3.2015.15713
}

\begin{abstract}
After the long period of international isolation in which Spain was plunged after the civil war, the regime revealed in the fifties an openness attitude towards the outside world within culture as well as an unequivocal willingness of modernisation. In these years began to appear for the first time some signs of acceptance and even promotion of avant-garde art within the official authorities, such as the Hispano-American Art Biennials, the Spanish representation in the Biennials of Venice, Sao Paolo and Alexandria, and a series of exhibitions outside our borders between I959 and 1964. The exhibition Arte de América y España (Art of the Americas and Spain) was the culmination of the work carried out by the Ministerio de Asuntos Exteriores, at a time in what was termed the exhaustion of Informalism, a tendency that had been exploited insistently in the exhibitions sponsored by the regime.
\end{abstract}

Keywords

Francoism; Informalism; Hispano-American Art Biennial; Cultural Policy

\section{Resumen}

Tras el largo período de aislamiento internacional en que España se vio sumida tras el final de la guerra civil, en los años cincuenta pudo observarse por parte del régimen una apertura hacia el mundo exterior en el ámbito cultural así como una inequívoca voluntad de modernización. En estos años comenzaron a aparecer por vez primera muestras de aceptación e incluso de promoción del arte de vanguardia dentro de las instancias oficiales como las Bienales Hispanoamericanas de Arte, la representación española en las Bienales de Venecia, Sâo Paulo o Alejandría, o una

1. Profesora Contratada Doctor, Departamento de Historia del Arte, Universidad Nacional de Educación a Distancia (gtusell@geo.uned.es). 
serie de exposiciones que tuvieron lugar fuera de nuestras fronteras entre $1959 \mathrm{y}$ 1964. La exposición Arte de América y España significó el culmen de esta labor realizada por el Ministerio de Asuntos Exteriores, en un momento en que se asistía ya a lo que se denominó el agotamiento de un informalismo que había sido utilizado insistentemente en las exposiciones patrocinadas por el régimen.

Palabras clave

Franquismo; Informalismo; Bienal Hispanoamericana de Arte; Política cultural 
AT THE BEGINNING OF THE DECADE of the fifties, Franco's regime fought to make a place for itself on the international scene after the isolation it had experienced at the end of the Spanish Civil War. The United Nations, created at the end of World War II, decided to cut off diplomatic relations with Spain as long as the regime continued to resemble those fascist countries that had been defeated. Most of the ambassadors had been withdrawn from Spain, with the sole exception of those of Portugal, Switzerland (in a very strict interpretation of its neutrality), the papal nuncio, and the representative of Ireland, a country with a very Catholic tradition. This was why Franco set himself the task of overcoming this isolation by taking advantage of the existing division between the victors of the World War and the favourable attitude of the Latin American nations and, to a lesser extent, the Arabs. The United States adopted a changeable political attitude with respect to the regime for, although it did make known its demands that Franco should give up power, it maintained a predominantly military interest in Spain centred on the cession of air space that would serve as a bastion of resistance and a base for a counteroffensive.

Franco took advantage of cultural politics to win support in Latin America by ordering a substantial increase of forty percent in the allotment for this purpose. At the same time, he carried out an important administrative change by transforming the Consejo de la Hispanidad (Hispanic Council) into the new Instituto de Cultura Hispánica (Institute for Hispanic Culture) that would develop an important program of exhibitions, including the Latin American Art Biennials, and later on in I963, Arte de América y España (Art of the Americas and Spain), the exhibition that would bring together the cultures of Spain and Iberoamerica. From that moment on Spanish culture would present itself as the promotor of a peculiar traditional Catholic way, capable of rivalling other more materialistic options and aided by the fact that a sector of Latin American opinion was in favour of the regime.

Spain was aware of the bonds that united it with Latin America and the propaganda task that it could carry out in those countries, thanks to the effective instrument of cultural politics. José Miguel Ruiz Morales, the Director General of Cultural Relations, expressed this idea in an address to a group of future diplomats: 'In the great dilemma that is tearing the world apart today between East and West, Spain has been called upon to the 'bridge' of understanding that will set us on the road to harmony, always in pursuit of spiritual solutions, and always against the supremacy of materialism.'2 The work carried out by the Ministerio de Asuntos Exteriores in support of abstract art culminated in the organization of its most ambitious exhibition, Arte de América y España (Art of the Americas and Spain). The show, inaugurated in Madrid in I963, travelled throughout Spain and parts of Europe. It included over six hundred works by young artists from our country, Latin

2. Ruiz Morales, José Miguel: 'Relaciones Culturales en la teoría y en la práctica,' (Cultural Relations in Theory and Practice), lecture given at the Escuela Diplomática, October 1958, in La Dirección General de Relaciones Culturales y Científicas, 1946-1996. Madrid, Ministerio de Asuntos Exteriores, 1996, 35. 'En la gran disyuntiva que hoy desgarra al mundo, Oriente-Occidente, España está llamada a ser "alcántara", el "puente" de entendimiento que llevará a la concordia, en pos siempre de soluciones espirituales, y en contra siepre de la primacía de la materia.' 
America, the United States, and Canada. The content illustrates what was termed the exhaustion of Informalism, a tendency that had been exploited insistently in the exhibitions sponsored by the regime. The exhibition celebrated the final moments of the so-called 'crisis' of Informalism that affected Europe as a whole, given that, the following year Robert Rauschenberg was awarded First Prize at the xxxil Venice Biennale, with the consequent recognition of Pop Art.

The idea of organizing a great exhibition of contemporary art that would bring together the experience of Spanish, Latin American, and North American artists had been in the making since the beginning of the sixties in the Dirección General de Relaciones Culturales. The entity in charge of carrying out this ambitious project was the Instituto de Cultura Hispánica $(\mathrm{ICH})$, a dependency of the Ministerio de Asuntos Exteriores (Ministry of Foreign Affairs). This ministry was responsible for the Hispanoamerican Art Biennials created in I95I, the exhibitions that introduced the young artists of Spain and the Americas to an international audience.

The abrupt interruption of these biennials ${ }^{3}$ caused the Institute to rethink about orienting its activities toward the promotion of young Spanish and Latin American artists. In accordance with its plans, the show would bring together around three hundred works and would include paintings, drawings, and prints. It would begin in Madrid and continue on to Barcelona. In accordance with the norms set forth by the Instituto de Cultura Hispánica, 'artists from the Americas, Spain, and the Philippines, between the ages of 25 and 45' were invited to participate in the sections of painting, drawing, and prints, with prizes to be awarded by an international jury. Moreover, it was planned to exhibit the show in several European cities with the collaboration of the Dirección General de Relaciones Culturales 'for a period no longer than eight months ${ }^{4}$.'

The Instituto de Cultura Hispánica $(\mathrm{ICH})$ tried to give the organization of such magnitude a political aspect, as its director, Gregorio Marañón, explained in a report to the Minister of Foreign Affairs: 'Those artists who are usually active left-wingers have been systematically alienated from Spain by signing manifestos and proclamations; therefore it is more important to approach those who are not yet completely defined and who are more prominent for their artistic creations. ${ }^{5}$

Luis González Robles, Head of the Department of Exhibitions of the $\mathrm{ICH}$, was appointed curator of the exhibition. He had a long career in organizing Spanish

3. After the III Bienal Hispanoamericana de Arte in Barcelona in 1955 it was agreed to hold the fourth exhibition in Caracas. Nevertheless, the Venezuelan capital was obliged to reject the proposal because it was on the eve of legislative elections and lacked the necessary funds for both events. Subsequently it was to be held in Quito in March 1961 after the XI Pan American Conference, but bureaucratic problems and difficulties of lending works abruptly interrupted the project. Archivo de Ministerio de Asuntos Exteriores (AMAE), Leg. R. 5229, Expte. 67 y Leg. R. 5413, Expte. 5 .

4. Normas por las que se regirá la exposición El Arte Actual de América y España. Madrid, July 1962. Archivo General de la Administración (AGA), Sección Cultural, Caja 733. 'artistas de América, España y Filipinas cuya edad está comprendida entre los 25 y 45 años' ... 'durante un período no mayor de ocho meses.'

5. Marañón, Gregorio: 'Informe sobre la exposición Arte Actual de América y España. Madrid, 31 October 1962. AMAE, Leg. R. 11072, Expte. 1. 'Los artistas que militan generalmente en campo de izquierdas se han alejado sistemáticamente de España firmando manifiestos y proclamas, y por ello, es más importante acercarse a aquellos que no están completamente definidos y que están colocados a la cabeza en sus creaciones artísticas.' 
representation in the Venice, Sao Paulo ${ }^{6}$, and Alexandria biennials, as well as a series of exhibitions of Spanish abstract art sponsored by the Ministry of Foreign Affairs at the end of the fifties and beginning of the sixties ${ }^{7}$. González Robles travelled to the Americas during the summer of 1962 with the purpose of selecting works for the show. His travels took him to the United States, Mexico, Canada, Guatemala, El Salvador, Honduras, Nicaragua, Costa Rica, Panama, Jamaica, Haiti, the Dominican Republic, Venezuela, and Trinidad. In regard to Spain, he had planned to present approximately thirty artists, the largest number together with Brazil, in accordance with four broad categories. The following names were preselected:

* Figurative Expressionism: Manuel Alcorlo, Juan Barjola, Máximo de Pablo, Antonio Zarco

* Abstract Expressionism: Enrique Gran, José María de Labra, Antonio Lorenzo, Jaime Muxart, Jesús de la Sota, Senén Ubiña

* New Expressive Materials: Josep Guinovart, Ignacio Yraola

* Drawing: Enrique Brinkmann, Antonio Poveda, José Vento, Fernando Zóbel

* Prints: J.A. Cuni, Jesús Núñez, César Olmos, Juan Vila Casas

In the opinion of González Robles, these artists were 'known to be artistically reliable, and also for their many awards, but they had not been sufficiently recognized abroad ${ }^{8}$. Thus this exhibition could be a great opportunity for them. As we shall see later on, some artists withdrew their names and several other artists were added to the list.

To complete this initial collection the Dirección General de Bellas Artes enlisted the help of the critic Rafael Santos Torroella and the Director of the Museo de Arte Contemporáneo, Fernando Chueca. Aside from recommending that a section on sculpture should be included and indicating the problems that might arise from limiting the age of the participants, they proposed including other young Spanish artists such as Albert Ràfols Casamada, Carmen Laffón, Xavier Corberó, Cristino Vera, Eusebio Sempere, Manuel Hernández Mompó, Amalia Avia, Antonio López, and Juan Hernández Pijuán`.

In all, González Robles finally selected I85 artists from among painters, sculptors, and print-makers who began to send their works to Spain at the beginning of 1963. The more than 600 works presented would serve to show, in the words of the curator, 'a complete picture of all the present-day tendencies' that were currently

6. For the work of Luis González Robles in the Sao Paulo Bienal, see Tusell García, Genoveva: 'González Robles, comisario español en Sao Paulo' in the catalog of the exhibition España en la Bienal de Sao Paulo bajo el comisariado de Luis González Robles, Alcalá de Henares (Madrid), Museo Luis González Robles and Universidad de Alcalá, 2009, pp. 11-22.

7. For an account of these exhibitions see GonzÁlez Robles, Luis: 'Mis recuerdos de aquella década', in the catalog of the exhibition Madrid. El arte de los 60. Madrid, Comunidad de Madrid, 1990, pp. 23-29; and the article by Tusell García, Genoveva: 'The Internationalisation of Spanish Abstract Art in its Official Exhibitions (1950-1962)' in Third Text. Critical Perspectives on Contemporary Art \& Culture. London, Routledge, vol. 20, 2006, pp. 241-249.

8. Report by Luis González Robles, Madrid, January 1963. AGA, Sección Cultura, Caja 886. '...de reconocida solvencia artística, muchos galardones nacionales, pero que no han sido lo suficientemente reconocidos en el extranjero.'

9. Written and signed by Rafael Santos Torroella and Fernando Chueca and addressed to the Director General of Fine Arts, Gratiniano Nieto. Dated Madrid, 11 January 1963. AGA, Sección Cultura, Caja 886. 
in vogue in the Americas. This would include 'figurative art dealt with in a revolutionary spirit, alongside the various manifestations of non-formal $\operatorname{art}^{10}$.' The fact that their works would be exhibited in Europe was an added incentive for the most important artists' decision to participate in the show. Among those artists chosen were Fernando Botero (Colombia), Jasper Johns (USA), Robert Rauschenberg (USA), Michael Ponce de Leon (USA), and Norman Narotzky (USA), together with the Spaniards Juan Barjola, Luis Feito, Juan Genovés, Modest Cuixart, Francisco Farreras, Gerardo Rueda, José Vento, Fernando Zóbel, Josep Guinovart, José María de Labra, César Manrique, Cirilo Martínez Novillo, Álvaro Delgado, Manuel Hernández Mompó, Máximo de Pablo, Antonio Suárez, and Joan Josep Tharrats ${ }^{\text {II }}$.

Luis González Robles also submitted a report in which he explained the political, cultural, and artistic importance of this exhibition, which was about to become one of the major large-scale projects carried out by the Ministry of Foreign Affairs in regard to cultural politics. In the political sphere, he pointed out that this was the first time that the tendencies in vogue in the Americas were gathered together in such a complete show. Moreover, they reaped the most outstanding fruits of modern art 'at a moment when Russia is severely restricting the possibilities of art by enclosing it in the rigid demands of Socialist Realism ${ }^{12}$.' Within the cultural sphere, the exhibition would not only serve to show the high level of the young art of Spain, but it would also bring to light the existence of the great affinity between American and Spanish artists.

A fact that should be pointed out concerning the organization of the show was the renunciation of Manuel Viola to take part in the exhibition. The painter communicated his decision to González Robles by way of a letter in which he expressed his renunciation in the following terms: '(...) by virtue of the fact that certain hastily precipitated events of public notoriety have recently taken place, and in my unwavering position as a defender of human rights, I am informing you that I hereby renounce my participation in the official exhibition, El Arte Actual de América y España ${ }^{13}$.' Manuel Viola, who had lived in exile in Paris and in Prague until I949, refused to participate in the exhibition in protest for the execution of Julián Grimau in April 1963 for alleged crimes committed in the Civil War, after a trial in which the necessary legal requirements were not carried out. In 1964, however, the painter returned to the official sphere when he was chosen to show in the Spanish

10. González Robles, Luis: 'Nota Informativa. Exposición Arte de América y España. Madrid, 2 February 1963. AMAE, Leg. R. 11072, Expte. 1. '...un panorama completo de todas las tendencias actuales' '...la figuración tratada con espíritu revolucionario y actual y junto a ella las diversas manifestaciones de lo no formal.'

11. 'Relación de artistas plásticos que participarán en la exposición Arte de América y España.' AmAE, Leg. R. 11072, Expte. 1.

12. González Robles, Luis: 'Informe sobre la exposición Arte de América y España sent by the Director of the Instituto de Cultura Hispánica, Gregorio Marañón, to Fernando María Castiella, Minister of Foreign Affairs, Madrid, 13 May 1963. AMAE, Leg. R. 11072, Expte. 1. '...en un momento en que Rusia restringe duramente Is posibilidades al arte encerrándole en las rígidas exigencias del Realismo Socialista.'

13. Letter from Manuel Viola to Luis González Robles, Madrid, 25 Abril 1963. AMAE, Leg, R. 11072, Expte. 1. '(...) en virtud de haberse precipitado ciertos acontecimientos de pública notoriedad, y en mi indeclinable posición de defensor de los derechos humanos, te comunico por la presente mi renuncia a mi participación a la muestra oficial El Arte Actual de América y España.' 
pavilion of the Venice Biennale. González Robles informed the Director General of Cultural Relations of his decision:

[Viola] wishes, by all means, to forget the error he committed when he 'backed out of' 'Arte de América y España'. It was of no consequence, and he didn't bother to explain his position to anyone, particularly to any of the foreign critics that were here. Anyway, it seems that he has now decided to behave himself ${ }^{14}$.

The exhibition was inaugurated by General Franco ${ }^{15}$ on I8 May 1963, in Madrid, in the Palacios de Cristal and Velázquez in the Parque del Retiro. The Caudillo was accompanied by his wife, the Ministers of Foreign Affairs, National Education, and Information and Tourism, the Director of the $\mathrm{ICH}$, and the curator of the exposition. On the occasion of the show, a press competition was organized and a Congress of Hispanic Institutions was held in Madrid in June, with over 300 participants from 37 countries. On I August the exhibition Arte de América y España opened in Barcelona, also in two venues: the Palau de la Virreina for drawings and prints and the Antiguo Hospital de la Santa Cruz for painting.

The carefully edited catalog was presented by the Director of the IсH and included texts by prominent art critics such as José Pedro Argull, José de Castro Arines, and Alexandre Cirici Pellicer. Juan Ignacio Macua, the person in charge of extensive press coverage of the exhibition, emphasized its importance with these words: 'Almost 600 works together is something that is not seen every day. It is even more unusual if we take into account that these works have come from every country in the Americas, and that this is the first time they can be seen all in one place. (...) the exhibition Arte de América y España goes beyond the limits of criticism or simple information about the plastic $\operatorname{arts}^{16}$.

Just as in the three previous announcements of competitions of the Bienales Hispanoamericanas de Arte, a series of prizes were awarded in the different categories of works represented in Arte de América y España. The prizes were distributed in proportion to the number of artists representing each country. Although the Spanish section had the most artists, it was excluded from the competition. Brazil, Argentina, and the United States each received two prizes, while nine countries received only one. The Gold Medal for painting was awarded to the Hispano-Argentine painter, José Antonio Fernández-Muro, the Guatemalan, Rodolfo Abularach,

14. Letter from Luis González Robles to Alfonso de la Serna, Director General of Cultural Relations, Madrid, 17 February 1964. AMAE, Leg. R. 11068, Expte. 21. '[Viola] desea por todos los medios hacer olvidar el error que cometió cuando su "espantá" de Arte de América y España. Aquello no trascendió, tampoco se preocupó mucho de explicar su postura a nadie, sobre todo a ninguno de los críticos extranjeros que tuvimos aquí, en fin que ahora parece ser que se comportará como Dios manda.'

15. The NODO (official Spanish newsreel) covered the inauguration on 27 May 1963. http://wwW.rtve.es/filmotecal no-dot-1064/1468856/.

16. Macua, Juan Ignacio: 'La exposición Arte de América y España' in Artes, no. 37, Madrid, 8 May 1963. The magazine Aula 63 devoted a special supplement to the competition. 'Casi seiscientas obras juntas no es una cosa de todos los días. Más raro aún si tenemos en cuenta que estas obras proceden de todos los países de América y que por primera vez se ven juntas (...) la exposición Arte de América y España sobrepasa los límites de una crítica o una información de artes plásticas.' 
received the Silver Medal for drawing, and the Silver Medal for prints went to the Brazilian, Roberto de Lamónica.

Before travelling to the major capitals of Europe, the exhibition toured the rest of Spain, although not in its entirety. Salamanca, Seville, Valencia, San Sebastián, and Bilbao were included in the showing, which ended in December 1963.

Once the exhibition in Madrid was inaugurated, its curator, Luis González Robles set about planning its continuation in Europe. The sheer size of the show, comprising more than 600 paintings, drawings, and prints, necessarily imposed a reduction of works in order to transport and show them more easily, given that it is almost impossible to find spaces large enough in all those cities to be able to exhibit them all together.' In order to avoid possible disappointments among the artists and not leave out anyone, it was decided to choose one work by each painter and two drawings and two prints by the other artists. Thus the number of paintings was reduced to II 4 works and that of drawings and prints to 220. Moreover, while the painting exhibition would follow a particular itinerary, drawings and paintings would be shown in different cities 'to achieve a double effect of cultural activity ${ }^{17}$.'

Contacts were begun in July to find the proper places to house the exhibition, for there was very little time to organize the travelling show. The number of works was so large that it was difficult to find spaces that were available on such short notice, for most of the venues were taken up years in advance. Some institutions were reluctant to hold a joint showing of Spanish and Latin American painting because they considered Latin American art to be less important and uninteresting, preferring instead an exhibition only of Spanish artists. Finally, the cost of subsidizing a travelling show was expensive, since the $\mathrm{ICH}$ would have to pay the expenses for transportation, insurance, installation, and catalogues.

Once the problems of organization were sorted out, the itinerary began with the presentation of paintings from Arte de América y España in the Royal Palace of Naples on Io December 1963. The inauguration was attended by the Secretary General of the $\mathrm{ICH}$, the Spanish consul in Naples, and the curator of the exhibition. The cultural attaché of the Spanish embassy in Rome, José María Alonso Gamo, representing the ambassador, spoke a few words in which he expressed 'Spain's intention to act as the spokesman in Europe for the principal artistic tendencies of the American nations at the present time ${ }^{18}$.

From there the exhibitions traveled to Rome, where negotiations were first carried out with the director, Palma Bucarelli, and the critic, Giulio Carlo Argan, to show it in the Gallery of Modern Art; but eventually the project fell through ${ }^{19}$. The

17. González Robles, Luis: 'Arte de América y España Itinerario de la exposición por Europa'. Madrid, May 1963. AMAE, Leg. R. 11072, Expte. 4. '...para poderlas transportar y exhibir con facilidad, ya que es casi imposible encontrar en todas las ciudades locales amplios para poder exhibirlas en sus totalidad.' '...consiguiendo así un doble efecto de actividad cultural.'

18. Dispatch no. 2754/4 from Alfredo Sánchez Bella, the Spanish ambassador in Rome, to Fernando María Castiella, Minister of Foreign Affairs, Rome, 12 December 1963. AMAE, Leg. R. 11072, Expte.2. '...la intención española de servir de portavoz para dar a conocer en Europa las principales directrices del arte de los pueblos americanos en el momento actual.'

19. Regarding these negotiations, see the letter from Luis González Robles to Alfonso de la Serna, Director 
works were finally shown at the Museum of Arts and Popular Traditions of Rome, and Luis González Robles took charge of installing the panels and organizing the paintings. The exhibition was inaugurated on I5 January I964 and was attended by the Spanish ambassador in Rome, Alfredo Sánchez Bella, the director of the museum, and the cultural attaché, José María Alonso Gamo, who said a few words about the significance and content of the exhibition ${ }^{20}$. Negotiations were begun in Italy to exhibit in other cities, but nothing came of it. The Vincenzo Mormino Foundation in Palermo and the Museum of Modern Art in Milan were mentioned, but unfortunately they were unavailable at that time.

From Rome the works went on to Switzerland where Luis González Robles was on hand to set up the exhibition. Arte de América y España was inaugurated in the Kunstmuseum of Bern on 29 February I964. In the words of the curator, its rooms were 'magnificent, ample, and high, and showed off the works splendidly ${ }^{21}$.' On the occasion of the inauguration, Professor Huggler, the Director of the Museum, gave a lecture analysing the main lines of the exhibition and thanking Spain for the possibility of being able to see the painting of the Americas, hitherto unknown in his country $^{22}$. The show awakened a great interest both in the critics and in the general public, whose attendance numbered over five thousand people. After it was over the paintings were handed over to the Consul General of Spain in Berlin. Although negotiations had concluded to exhibit in Geneva, the Spanish ambassador rejected the proposal because he felt that it was more important to give precedence to Berlin.

We have very little information about the painting exhibition, Arte de América y España, in Berlin. Because the consul general of Spain in that city, Antonio Espinosa, took charge of its installation and organization, González Robles did not have to go to Berlin. The exhibition was inaugurated on Io April I964, in the rooms of the Kongresshalle ceded by the Berlin senate for that purpose. In spite of everything, the curator complained to José María Rubio, the person in charge of the Sección de Exposiciones of the Dirección General de Relaciones Culturales, because of the lack of information about the exhibition in Berlin: 'I am very worried about the complete lack of official news about our exhibition Arte de América y España in Berlin. I don't know what to say to our director, our subdirector, or the artists ${ }^{23}$.'

What is certain is that the show was exhibited throughout April in Berlin after negotiations failed to hold it in the Kunstverein in Hamburg and the Instituto de España in Munich. In any case, the Dirección General de Relaciones Culturales

\footnotetext{
General of Cultural Relations, Mexico DF, 27 October 1963, which was also sent to Giulio Carlo Argan the same day. AMAE, Leg. R. 11072, Expte.2.

20. Letter from Luis González Robles to Alfonso de la Serna, the Director General of Cultural Relations, Rome, 16 January 1964. AMAE, Leg. R. 11072, Expte. 2.

21. Letter from Luis González Robles to Alfonso de la Serna, Director General of Cultural Relations, Bern, 29 February 1964. AMAE, Leg. R. 11072, Expte. 2.

22. Dispatch no. 224 from the Spanish ambassador in Bern, Juan Pablo de Lojendio, to the Dirección General de Relaciones Culturales, 8 Abril 1964. AMAE, Leg. R. 11072, Expte. 2

23. Letter from Luis González Robles to José María Rubio, Jefe de la Sección de Exposiciones de la Dirección General de Relaciones Culturales, Madrid, 23 April 1964. AMAE, Leg. R 11072, Expte. 2. 'Estoy bastante preocupado por la falta total de noticias oficiales sobre nuestra exposición Arte de América y España en Berlín. Nada sé decir a nuestro director, a nuestro subdirector, a los artistas.'
} 
notified the Spanish consul in Berlin that, once the exhibition was over, the works should be returned to the Instituto de Cultura Hispánica in Madrid in preparation for their eventual showing in Lisbon, although we do not know if it was ever held.

As for the section devoted to drawings and prints, its European journey began few months later than that of painting. The exhibition Arte de América y España was inaugurated on 3 March 1964 in a version reduced to Io9 works. The act took place in Lisbon in the Palacio Foz, the seat of the Secretariado Nacional de Información, and was attended by Enrique Suárez Puga, the Secretary of the Instituto de Cultura Hispánica, Manuel Fraga, the Minister of Information and Tourism, and the Spanish ambassador, José Ibáñez-Martín, in addition to the President of the Republic of Portugal and other national dignitaries ${ }^{24}$.

Apparently the exhibition of drawings and prints was initially meant to continue on to Bordeaux, Strasbourg, Florence, Geneva, Toulouse, and Zurich. But given the difficulties that arose in organizing the European journey, mainly in connection with the venues, it is possible that it was only held in Lisbon, the only show for which we have any information. When he was notified of the project, the consul general in Bordeaux pointed out the scant possibilities for success in that city due to the fact that 'the public hardly shows any interest in the artistic manifestations of painting, particularly if they have anything to do with modern abstract art which is so questioned and questionable ${ }^{25}$. In regard to Florence, again they came up against the unsolvable problem that the main exhibition venues, including the Palazzo Strozzi, which they considered the most suitable, had already been reserved in advance. As for Zurich, negotiations were equally unfruitful because, on the one hand, the Kunstmuseum was not big enough to show more than 70 or 80 works and, on the other, the Kunsthalle had been taken up for the entire year.

The same occurred with many other European cities where they had intended to exhibit paintings from Arte de América y España. Initially ambitious, it was obliged to reduce its plans due to the problems that had arisen. The Amsterdam Municipal Museum refused because the proposed dates were already filled up and they had already programmed a show of Spanish art. Both the Tate Gallery in London and the Edinburgh Festival also rejected it. As for Paris, where they had thought to touch off the European show, negative replies were received from the Museum of Modern Art of the Ville de Paris, the Galèrie Charpentier, and Unesco.

In spite of everything, the European tour was a critical success. The international press acclaimed it enthusiastically both because of the fact that these works had never been shown before in Europe and the quality of the works selected. In the opinion of its curator, Luis González Robles, the influence of this important show was decisive for the artists of the time because 'the impact was fundamental, not

24. Dispatch no. 209 from the Spanish ambassador in Lisbon, José Ibáñez Martín, to the Dirección General de Relaciones Culturales, Lisbon 3 March 1964. AmAE, Leg. R. 11072, Expte. 3.

25. Letter from the consul general of Spain in Bordeaux, José R. Gómez-Acebo, to the Dirección General de Relaciones Culturales, Bordeaux, 7 August 1963. AmAE, Leg. R. 11072, Expte. 3. '...interés que este público demuestra por las manifestaciones artísticas de pintura y muy especialmente si éstas se refieren al arte abstracto moderno tan discutido y discutible.' 
only on the participating artists but also on those who, for various reasons, were left out. Many of them recognize today that they painted differently after that exhibition. When they saw with their own eyes the lines that had been intuited in the reviews, and seeing them together and in opposition to each other, they realized that this merited serious reflection and even a gratifying confirmation of their own work ${ }^{26}$ ' This exhibition shows not only the task that the Ministerio de Asuntos Exteriores set for itself in sponsoring Spanish avant-garde art, but also the will of the regime for Spain to become the port of entry for Latin American art in Europe, as evidenced by the initiative that began with the Hispanoamerican Art Biennials ${ }^{27}$.

26. González Robles, Luis: 'Mis recuerdos..., op. cit. p. 24. '...no sólo entre los artistas participantes, sino también entre los que por distintas razones quedaron fuera, el impacto fue fundamental. Muchos de ellos reconocen todavía hoy que pintaron distinto a partir de aquella exposición, que ver al natural las líneas que en las revistas se intuían y verlas juntas y enfrentadas supuso una seria reflexión y, a veces, una gratificante confirmación del trabajo propio.'

27. MacuA, Juan Ignacio; 'La Libreta Negra del Comisario', in the catalog of the exhibition España en la Bienal de Sao Paulo bajo el comisariado de Luis González Robles. Alcalá de Henares (Madrid). Museo Luis González Robles and Universidad de Alcalá, 2009, pp. 7-9. 


\section{BIBLIOGRAPHY}

AA.vv.: La Dirección General de Relaciones Culturales y Científicas. 1946-1996. Madrid, Ministerio de Asuntos Exteriores, I996.

Calvo Serraller, Francisco (ed.): España. Medio Siglo de Arte de Vanguardia. 1939-I985. 2 vols. Madrid, Fundación Santillana y Ministerio de Cultura, I985.

GonzÁlez Robles, Luis: 'Mis recuerdos de aquella década', Catálogo de la exposición Madrid. El arte de los 6o. Madrid, Comunidad de Madrid, I990, pp. 23-29.

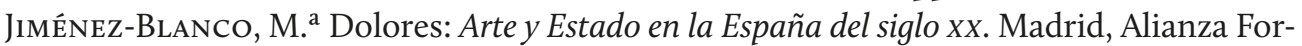
ma, I989.

JimÉnez-Blanco, M. ${ }^{a}$ Dolores \& Lubar, Robert S. (eds.): Contemporary Trasatlantic Dialogues. Center for Spain in America, 2013. http://www.ceeh.es/media/docs/dialogos_trasatlanticos_web.pdf.

MacuA, Juan Ignacio: 'La exposición “Arte de América y España”, Artes, 37, Madrid, 8/05/1963. La revista Aula 63 dedicó una separata especial a este certamen.

-: 'La Libreta Negra del Comisario', Catálogo de la exposición España en la Bienal de Sao Paulo bajo el comisariado de Luis González Robles. Alcalá de Henares (Madrid), Museo Luis González Robles y Universidad de Alcalá, 2009, pp. 7-9.

Marzo, Jorge Luis: ¿Puedo hablarle con libertad, excelencia? Arte y poder en España desde I950. Murcia, CENDEAC, 2010.

Tusell García, Genoveva: 'The internationalisation of Spanish Abstract Art in its Official Exhibitions (1950-I962)', Third Text. Critical Perspectives on Contemporary Art \& Culture, 20, 2006, pp. 24I-249.

-: 'González Robles, comisario español en Sao Paulo', Catálogo de la exposición España en la Bienal de Sao Paulo bajo el comisariado de Luis González Robles. Alcalá de Henares (Madrid), Museo Luis González Robles \& Universidad de Alcalá, 2009, pp. II-22. 
AÑO 2015

NUEVA ÉPOCA

ISSN: $1130-4715$

E-ISSN 2340-1479

Dossier - Víctor Nieto Alcaide \& Genoveva Tusell: Arte en el franquismo: tendencias al margen de una ideología de estado / Art in the Franco era: tendencies on the fringe of a State ideology

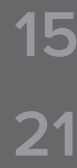

Víctor Nieto Alcaide \& Genoveva Tusell (COORds.) Introduction / Introducción

\section{GENOVEVA TUSELL (GUEST EDITOR)}

The exhibition Arte de América y España (1963): the continuation of the spirit of the Hispanoamerican biennials / La exposición Arte de América y España (1963), continuadora del espíritu de las bienales hispanoamericanas

33 Eva March RoIG

Franquismo y Vanguardia: III Bienal Hispanoamericana de Arte / Francoism and avant-garde: the $3^{\text {rd }}$ Hispanoamerican Biennale of Art

55 SARA NÚÑEZ IZQUIERDO

La renovación de la arquitectura salmantina en la década de los cincuenta / Salamanca's architecture renewal during the Fifties

\section{5}

\section{M. ${ }^{A}$ Begoña Fernández Cabaleiro}

La Escuela de Madrid en la crítica de arte franquista: la «nunca rota» conexión con la vanguardia / The Escuela de Madrid in critic of art during Franco's government: the 'never broken' connection to the vanguard

105 RAúl Fernández Aparicıo

Saura y las Multitudes: de Goya a Munch / Saura and Multitudes: from Goya to Munch

\section{PILAR MUÑOZ LóPEZ}

Artistas españolas en la dictadura de Franco (1939-1975) / Spanish Women Artists during Franco's Dictatorship (1939-1975)

\section{3}

\section{Mónica Alonso Riveiro}

La invención de la familia: supervivencia, anacronismo y ficción en la fotografía familiar del primer franquismo / Invention of family: survival, anachronism and fiction in family photography during Francoism

\section{1}

\section{Mónica CARABIAS ÁlVARO}

Cuadernos de fotografía (1972-1974), una propuesta editorial para la difusión de una fotografía clásica y testimonial en el contexto y debate fotográfico español de los setenta / Cuadernos de Fotografía (1972-1974), a publishing proposal for the dissemination of a testimonial and classic photography in the context and Spanish photographic debate of the 1970 s
223 DANIEL A. VERdú SCHUMANN

La Sala Amadís (1961-1975): arte y/o franquismo / Sala Amadís, 1961-1975: art and/or Francoism

\section{5}

JUAN ALBARRÁN DIEGO

Lo profesional es político: trabajo artístico, movimientos sociales y militancia política en el último franquismo / The Professional is Political: Artistic Work, Social Movements, and Militancy in Late Francoism

\section{Miscelánea $\cdot$ Miscellany}

275 SERGI DOMÉNECH GARCÍA

La recepción de la tradición hispánica de la Inmaculada Concepción en Nueva España: el tipo iconográfico de la Tota Pulchra / The Reception of the Hispanic Tradition of the Immaculate Conception in New Spain: the Iconographic Type of Tota Pulchra

\section{INMACULADA ROdRÍGUEZ MOYA}

Un archipiélago para los borbones: fiestas regias en Mallorca en el siglo XVIII / An archipelago for the Bourbons: royal festivals in Majorca in the $18^{\text {th }}$ century

343 MARÍA RUIZ dE LOIZAGA

Tradición y modernidad en la obra de Antonio López / Tradition and Modernity in Antonio López's works

\section{Miguel Anxo Rodríguez GonzÁlez}

Del espectáculo cultural y sus efectos: arte y políticas culturales en Santiago de Compostela / The cultural spectacle and its effects: arts and cultural policies in Santiago de Compostela

\section{Reseñas · Books Review}

105 Silvestre, Federico L.: Los pájaros y el fantasma. Una historia del artista en el paisaje (JAVIER ARNALDO)

10 Capriotti, Giuseppe: Lo scorpione su petto. Iconografia antiebraica tra Xv e Xvı secolo alla periferia dello Stato Pontificio (BORJA FRANCO LLOPIS)

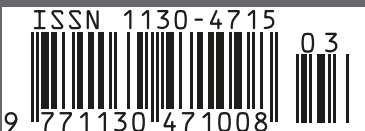

